\title{
PENINGKATAN SIKAP DEMOKRATIS DAN PRESTASI BELAJAR PESERTA DIDIK MELALUI MODEL PEMBELAJARAN GROUP INVESTIGATION (GI) PADA TEMA 8 KELAS IVA SD MUHAMMADIYAH PURWOKERTO Hafidzah Lulus Ujipriyati ${ }^{1}$, Sri Muryaningsih ${ }^{2}$, Tri Yuliansyah Bintaro ${ }^{3}$ ${ }^{1,2,3)}$ PGSD FKIP Universitas Muhammadiyah Purwokerto E-mail: ${ }^{1)}$ hafidzahlulusup@ gmail.com ${ }^{2)}$ srimuryaningsihump@gmail.com \\ ${ }^{3)}$ triyuliansyahbintaro@ump.ac.id
}

\begin{abstract}
Abstrak: Penelitian ini bertujuan untuk meningkatkan sikap demokratis dan prestasi belajar pada tema 8 Daerah Tempat Tinggalku melalui model pembelajaran Group Investigation (GI). Subjek penelitian adalah peserta didik kelas IVA berjumlah 22 peserta didik. Instrumen penelitian yang digunakan yaitu tes evaluasi, lembar observasi aktivitas guru, lembar observasi aktivitas peserta didik, lembar observasi sikap demokratis dan angket sikap demokratis. Hasil angket sikap demokratis pada siklus I memperoleh nilai rata-rata 3,24 dengan kategori baik dan meningkat ke siklus II sebesar 3,42 dengan kategori sangat baik. Peningkatan ini juga didukung dengan hasil observasi sikap demokratis peserta didik pada siklus I memperoleh nilai rata-rata sebesar 57\% dengan kategori cukup dan pada siklus II memperoleh nilai rata-rata sebesar $81 \%$ dengan kriteria sangat baik. Prestasi belajar peserta didik pada siklus I memperoleh rata-rata sebesar 72,68 dengan persentase ketuntasan sebesar $66 \%$ dengan kriteria baik, sedangkan pada siklus II memperoleh rata-rata sebesar 79,69 dengan persentase ketuntasan sebesar $81 \%$ dengan kriteria sangat baik. Penelitian ini dapat disimpulkan bahwa melalui penerapan model pembelajaran Group Investigation (GI) dapat meningkatkan sikap demokratis dan prestasi belajar peserta didik di kelas IVA SD Muhammadiyah Purwokerto.
\end{abstract}

Kata kunci: Sikap Demokratis, Prestasi Belajar, Model Pembelajaran Group Investigation (GI)

\begin{abstract}
This research aimed to improve the students' democratic behavior and learning achievement on theme 8 about Area of My Living Place through Group Investigation learning model. The subjects of this research were 22 fourth graders from Class A. The instruments of this research were evaluation test, observation sheets of teacher's and students' activity, observation sheet and questionnaire of students' democratic behavior. The result of democratic behavior questionnaire in cycle I showed that the average score was 3.24 which belonged to good and improved to 3.42 in cycle II which belonged to very good. This improvement was also supported by the observation result of students democratic behavior in cycle I whose average score was 57\% which belonged to fair and improved to $81 \%$ in cycle II which belonged to very good. The average score of students' learning achievement in cycle I was 72.68 with $66 \%$ of completeness that belonged to good and improved to 79.69 with $81 \%$ of completeness that belonged to very good. It could be concluded that Group Investigation learning model was able to improve the students' democratic behavior and learning achievement in Class IV A of SD Muhammadiyah Purwokerto.
\end{abstract}

Keywords: Democratic behavior, Learning Achievement, Group Investigation learning model 


\section{ELSE (Elementary School Education Journal) \\ Volume 3 Nomor 2 Agustus 2019 \\ P-ISSN: 2581-1800 E-ISSN: 2597-4122 \\ Email: else@um-surabaya.ac.id}

\section{PENDAHULUAN}

Pendidikan merupakan sarana yang berperan penting dalam menyiapkan sumber daya manusia yang berkualitas dan mampu bersaing di era global. Dalam upaya mengembangkan manusia yang berkarakter pemerintah mengembangkan pembelajaran di Sekolah Dasar (SD) dengan mengimplementasi Kurikulum 2013 dengan pendekatan pembelajaran berbasis tematik interegratif. Menurut Mulyasa (2013:170) pembelajaran tematik integratif adalah pembelajaran yang diterapkan pada tingkatan pendidikan dasar yang menyuguhkan proses belajar berdasarkan tema kemudian dikombinasikan dengan mata pelajaran lainnya. Implementasi pembelajaran menggunakan kurikulum 2013 masih terdapat permasalahan.

Berdasarkan hasil observasi di kelas IVA SD Muhammadiyah Purwokerto ditemukan berbagai masalah dalam proses pembelajaran di kelas diantaranya: peserta didik belum mampu menghargai kritikan dari temannya, kegiatan diskusi belum berjalan dengan baik karena masih terdapatnya peserta didik yang masih berpangku tangan dalam mengerjakan tugas secara kelompok, peserta didik belum mampu menghargai pendapat orang lain dan peserta didik belum memberikan kesempatan temannya untuk mengemukakan pendapat. Dengan demikian, peneliti menganalisis bahwa sikap demokratis peserta didik masih rendah. Menurut Mustari (2014:137) demokratis adalah cara berpikir, bersikap, dan bertindak yang menilai sama hak dan kewajiban dirinya dan orang lain.

Melihat kondisi atau permasalahan yaitu rendahnya sikap demokratis peserta didik tentu hal tersebut akan mempengaruhi prestasi belajar peserta didik. Hal ini juga terjadi di kelas IVA SD Muhammadiyah Purwokerto bahwa prestasi belajar peserta didik masih dikatakan rendah dengan dibuktikan peserta didik belum mencapai Kriteria Ketuntasan Minimal (KKM) yang ditentukan oleh Sekolah.

Berdasarkan hasil diskusi dengan guru kelas maka peneliti dan guru kelas IVA SD Muhammadiyah Purwokerto sepakat berkolaborasi mengatasi permasalahan rendahnya sikap demokratis dan prestasi belajar menggunakan model pembelajaran Group Investigation (GI) pada tema 8 Daerah Tempat Tinggalku. Melalui model pembelajaran Group Investigation (GI) peserta didik dapat berdiskusi aktif dan masing-masing peserta didik dapat mengungkapkan pendapatnya dengan baik. Slavin (2008:24) menyatakan bahwa model pembelajaran Group Investigation (GI) adalah model pembelajaran 


\section{ELSE (Elementary School Education Journal) \\ Volume 3 Nomor 2 Agustus 2019 \\ P-ISSN: 2581-1800 E-ISSN: 2597-4122}

kooperatif yang memberikan kesempatan peserta didik bekerja dalam kelompok kecil untuk menanggapi proyek kelas secara bersama.

Kelebihan dari model pembelajaran Group Investigation (GI) menurut Pranata (2016:26) adalah Group Investigation (GI) adalah model pembelajaran berbasis kelompok yang melibatkan peserta didik berpeluang untuk berdiskusi dan berpikir kritis sehingga menumbuhkan kehangatan antar peserat didik, kepercayaan, dan rasa hormat kepada orang lain. Dengan adanya kelebihan tersebut peneliti berkeyakinan model Group Investigation (GI) dapat meningkatkan sikap demokratis dan prestasi belajar peserta didik.

Berdasarkan paparan masalah yang terjadi, maka perlu melakukan penelitian tindakan kelas dengan judul "Peningkatan Sikap Demokratis dan Prestasi Belajar Peserta Didik melalui Model Pembelajaran Group Investigation (GI) Pada Tema 8 Kelas IVA SD Muhammadiyah Purwokerto".

\section{METODE PENELITIAN}

Penelitian ini merupakan Penelitian Tindakan Kelas (PTK). Arikunto (2015:1) menyatakan bahwa penelitian tindakan kelas merupakan penelitian yang memaparkan terjadinya sebab-akibat dari perlakuan, sekaligus memaparkan apa yang terjadi ketika perlakuan diberikan dan memaparkan seluruh proses sejak awal pemberian perlakuan sampai dengan dampak dari perlakuan tersebut.

Penelitian ini dilaksanakan dalam dua siklus, setiap siklus terdiri dari dua pertemuan. Penelitian ini terdiri dari tahap perencanaan (planning), pelaksanaan tindakan (acting), observasi (observing), dan refleksi (reflecting). Pengumpulan data diperoleh melalui beberapa teknik yaitu teknik tes dan non tes. Teknis tes berupa tes tertulis yang berbentuk soal isian singkat yang dilakukan disetiap akhir pertemuan, sedangkan teknik non tes yaitu lembar observasi guru, lembar observasi aktivitas peserta didik, lembar observasi sikap demokratis dan angket sikap demokratis peserta didik. Subjek penelitian tindakan kelas ini adalah kelas IVA berjumlah 22 peserta didik di SD Muhammadiyah Purwokerto Kecamatan Purwokerto Utara, Kabupaten Banyumas. 


\section{HASIL DAN PEMBAHASAN}

\section{Peningkatan Sikap Demokratis Peserta Didik}

Penelitian Tindakan Kelas (PTK) ini sikap demokratis peserta didik diukur dengan lembar observasi sikap demokratis peserta didik dan angket sikap demokratis peserta didik yang diberikan oleh guru pada akhir siklus I dan akhir siklus II. Ayun (2016:2647) menyatakan bahwa menanamkan pendidikan karakter demokratis bisa dilakukan dengan menciptakan suasana kelas yang demokratis dimana ditunjukkan dengan perilaku kecil seperti mengambil keputusan dalam kegiatan diskusi. meningkatkan sikap demokratis peserta didik. Berdasarkan hasil penelitian guru selalu menciptakan suasana pembelajaran dalam suasana demokratis.

Sikap demokratis merupakan sikap yang penting dalam proses pembelajaran karena dapat memberikan manfaat bagi peserta didik. Oleh karena itu, Kemendiknas memasukan sikap demokratis kedalam 18 nilai karakter bangsa. Kemendinas (2010:27) menyatakan bahwa indikator kelas sikap demokratis meliputi: 1) Mengambil keputusan kelas secara bersama melalui musyawarah mufakat, 2) Pemilihan kepengurusan kelas secara terbuka, 3) Seluruh produk kebijakan melalui musyawah dan mufakat, 4) Mengimplementasi modelmodel pembelajaran yang dialogis dan interaktif.

Hasil analisis data dalam penelitian tindakan kelas (PTK) tentang sikap demokratis peserta didik di kelas IVA SD Muhammadiyah Purwokerto mengalami peningkatan setelah menggunakan model pembelajaran Group Investigation (GI). Hal ini terlihat dari hasil rekapitulasi angket sikap demokratis dan hasil observasi sikap demokratis pada siklus I dan siklus II. Peningkatan sikap demokratis peserta didik dapat dilihat pada tabel 1 berikut:

Tabel 1. Peningkatan Angket Sikap Demokratis Peserta Didik

\begin{tabular}{cllcc}
\hline No & \multicolumn{1}{c}{ Indikator } & \multicolumn{1}{c}{ Pernyataan } & $\begin{array}{c}\text { Siklus } \\
\text { I }\end{array}$ & $\begin{array}{c}\text { Siklus } \\
\text { II }\end{array}$ \\
\hline 1. & $\begin{array}{l}\text { Membiasakan diri } \\
\text { bermusyawarah } \\
\text { dengan teman- } \\
\text { teman. }\end{array}$ & $\begin{array}{l}\text { Saya mau bertanya kepada guru } \\
\text { maupun teman-teman jika ada } \\
\text { materi pelajaran yang belum } \\
\text { dipahami. }\end{array}$ & 3,5 & 3,9 \\
& $\begin{array}{l}\text { Saya lebih baik bermain sendiri } \\
\text { dibandingkan mengerjakan } \\
\text { tugas kelompok. }\end{array}$ & 3,5 & 3,6 \\
2 & $\begin{array}{l}\text { Saya tidak mengabaikan } \\
\text { kemberikan } \\
\text { temandapat dari teman ketika } \\
\text { mengemukakan } \\
\text { pendapat }\end{array}$ & $\begin{array}{l}\text { Saya mengejek teman ketika dia } \\
\text { sedang berdiskusi. } \\
\text { tidak bisa menjawab dengan } \\
\text { benar pertanyaan dari guru }\end{array}$ & 2,2 & 2,0 \\
\hline
\end{tabular}




\begin{tabular}{|c|c|c|c|c|}
\hline \multirow[t]{2}{*}{3.} & $\begin{array}{l}\text { Menghargai } \\
\text { pendapat atau } \\
\text { kritikan temannya }\end{array}$ & $\begin{array}{l}\text { Saya memberikan ucapan } \\
\text { selamat ketika teman } \\
\text { mendapatkan nilai } 100 \text {. }\end{array}$ & 3,3 & 3,7 \\
\hline & & $\begin{array}{l}\text { Saya mengabaikan teman yang } \\
\text { sedang mengemukakan } \\
\text { pendapat di depan kelas. }\end{array}$ & 3,0 & 2,9 \\
\hline \multirow[t]{2}{*}{4.} & $\begin{array}{l}\text { Tidak memaksakan } \\
\text { kehendak kepada }\end{array}$ & $\begin{array}{l}\text { Saya jujur ketika melakukan } \\
\text { kesalahan yang saya perbuat }\end{array}$ & 3,4 & 3,7 \\
\hline & orang lain. & $\begin{array}{l}\text { Saya memaksa teman agar } \\
\text { menerima pendapat yang saya } \\
\text { ajukan }\end{array}$ & 3,4 & 3,5 \\
\hline \multirow[t]{4}{*}{5.} & $\begin{array}{l}\text { Menerima setiap } \\
\text { keputusan yang } \\
\text { disepakati bersama. }\end{array}$ & $\begin{array}{l}\text { Saya mendukung teman yang } \\
\text { akan menjadi ketua kelas, } \\
\text { walaupun teman pernah jadi } \\
\text { musuh }\end{array}$ & 3,4 & 3,5 \\
\hline & & $\begin{array}{l}\text { Saya marah ketika saya tidak } \\
\text { tepilih menjadi pemimpin }\end{array}$ & 3,4 & 3,7 \\
\hline & \multicolumn{2}{|r|}{$\begin{array}{l}\text { Jumlah } \\
\text { Rata-Rata }\end{array}$} & $\begin{array}{l}713 \\
3,24\end{array}$ & $\begin{array}{l}753 \\
3,42\end{array}$ \\
\hline & \multicolumn{2}{|c|}{ Kriteria } & Baik & $\begin{array}{c}\text { Sangat } \\
\text { Baik }\end{array}$ \\
\hline
\end{tabular}

Hasil angket sikap demokratis peserta didik berdasarkan tabel 1 menunjukkan bahwa adanya peningkatan nilai rata-rata dari siklus I ke siklus II melalui model pembelajaran Group Investigation (GI). Pada siklus I rata-rata sikap demokratis sebesar 3,24 dengan kategori baik dan pada siklus II meningkat menjadi 3,42 dengan kategori sangat baik. Hal tersebut diperkuat dengan hasil observasi sikap demokratis peserta didik kelas IVA SD Muhammadiyah Purwokerto dapat dilihat pada Gambar 1 berikut ini:

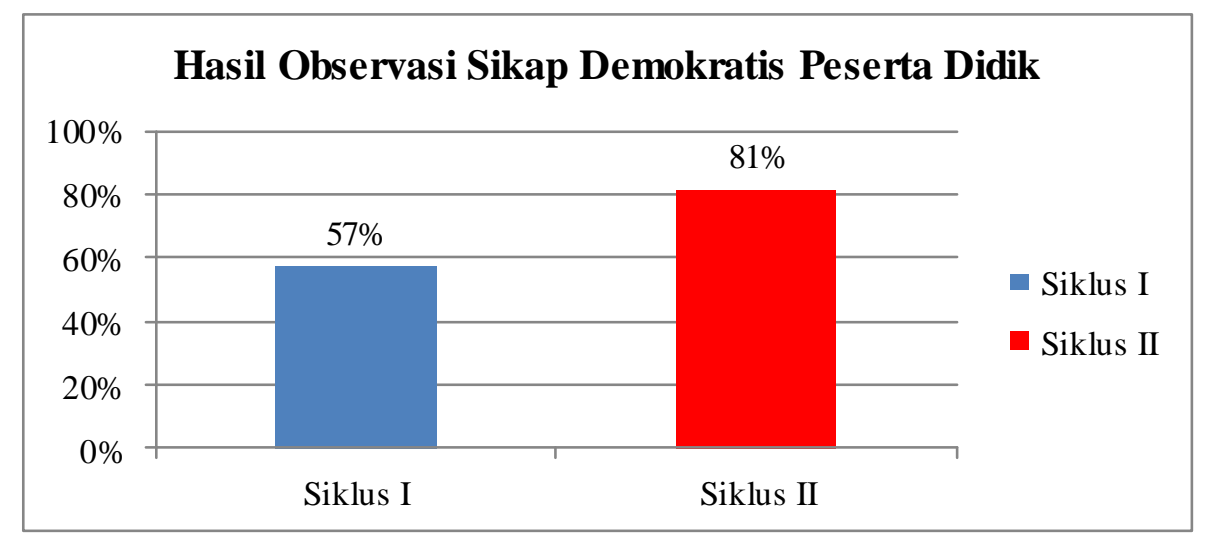

\section{Gambar 1. Histogram Hasil Observasi Sikap Demokratis}

Hasil observasi sikap demokratis peserta didik berdasarkan gambar 1 menunjukkan bahwa adanya peningkatan rata-rata dari siklus I ke siklus II. Dari siklus I rata-rata sikap demokratis sebesar 57\% dengan kriteria cukup sedangkan pada siklus II meningkat 
menjadi $81 \%$ dengan kriteria sangat baik. Dari kedua siklus tersebut menunjukkan adanya peningkatan sikap demokratis peserta didik.

Peningkatan sikap demokratis tidak terlepas dari pengaruh penerapan model pembelajaran Group Investigation (GI) terbukti dengan hampir keseluruhan peserta didik memiliki sikap demokratis pada saat kegiatan pembelajaran. Hal ini sejalan dengan penelitian yang telah dilaksanakan Baki, A, etc (2010) dengan judul penelitian The Application of Group Investigation Technique: The Views of the Teacher and Students yang menjelaskan bahwa model Group Investigation (GI) memberikan pengaruh yang sangat besar bagi peserta didik diantaranya: selama belajar kelompok para peserta didik senang belajar kelompok, peserta didik senang bekerja di kelompok, dan teknik penyelidikan kelompok ini berguna untuk melatih peserta didik melakukan beberapa peran. Dengan demikian dengan penggunaan model pembelajaran Group Investigation (GI) sangat berperan dalam pembentukan sikap demokratis peserta didik.

\section{Peningkatan Prestasi Belajar Peserta Didik}

Prestasi belajar merupakan salahsatu hasil yang biasanya dijadikan ukuran keberhasilan seseorang dalam belajar. Arifin (2011:12) berpendapat bahwa prestasi belajar pada umumnya berkenaan dengan aspek pengetahuan. Prestasi belajar sebagai indikator kualitas dan kuantitas pengetahuan yang telah dikuasai peserta didik. Dalam penelitian tindakan kelas ini peneliti menggunakan lembar tes evaluasi yang diberikan pada setiap akhir pembelajaran pada setiap siklus.

Peningkatan prestasi belajar peserta didik kelas IVA SD Muhammadiyah Purwokerto dalam penelitian tindakan kelas (PTK) selalu mengalami peningkatan. Hasil peningkatan prestasi belajar peserta didik kelas IVA SD Muhammadiyah Purwokerto dapat dilihat pada tabel 2 berikut ini

Tabel 2. Rekapitulasi Hasil Prestasi Belajar Peserta Didik

\begin{tabular}{llcc}
\hline No & \multicolumn{1}{c}{ Indikator } & Siklus I & Siklus II \\
\hline 1. & Rata-Rata per siklus & 72,68 & 79,69 \\
2. & Persentase Ketuntasan & $66 \%$ & $81 \%$ \\
3. & Kriteria & Baik & Sangat Baik \\
\hline
\end{tabular}

Tabel 2 di atas menunjukkan hasil peningkatan prestasi belajar peserta didik pada siklus I dan siklus II. Pada siklus siklus I nilai rata-rata siklus I yaitu 72,68 dan persentase ketuntasan $66 \%$ dengan kriteria baik. Kemudian meningkat pada siklus II yaitu sebesar 79,69 dan persentase ketuntasan sebesar 81\% dengan kategori sangat baik. 


\section{ELSE (Elementary Schod Education Journal) \\ Volume 3 Nomor 2 Agustus 2019 \\ P-ISSN: 2581-1800 E-ISSN: 2597-4122 \\ Email:else@um-surabaya.ac.id}

Berdasarkan hasil evaluasi yang dikerjakan peserta didik pada setiap siklusnya selalu mengalami peningkatan. Hal ini tidak terlepas dari adanya penggunaan model pembelajaran Group Investigation (GI). Hal ini juga sejalan dengan penelitian yang telah dilakukan oleh Arsy, dkk (2019) dengan judul penelitian Predict-Observe-Explain Strategy with Group Investigation effect on students" Critical Thinking Skill And Learning Achievement yang menyatakan bahwa model GI dalam pembelajaran memberikan manfaat untuk melatih peserta didik untuk menemukan pengetahuan baru mereka, untuk meningkatkan prestasi belajar mereka dan keterampilan berpikir kritis, serta untuk meningkatkan kualitas pembelajaran.

Berdasarkan hasil penelitian yang diperoleh terjadi peningkatan dari siklus I ke siklus II. Penerapan model pembelajaran Group Investigation (GI) dapat meningkatkan sikap demokratis dan prestasi belajar peserta didik pada tema 8 kelas IVA SD Muhammadiyah Purwokerto.

\section{KESIMPULAN DAN SARAN}

\section{Kesimpulan}

Berdasarkan penelitian yang dilakukan di SD Muhammadiyah Purwokerto maka dapat disimpulkan bahwa penerapan model pembelajaran Group Investigation (GI) dalam pembelajaran tematik pada tema 8 daerah tempat tinggalku dapat meningkatkan sikap demokratis peserta didik. Peningkatan ini terlihat dari semakin baiknya sikap demokratis peserta didik dalam menjalankan kegiatan pembelajaran. Peningkatan sikap demokratis tidak hanya dilihat dari hasil angket sikap demokratis, tetapi juga dapat dilihat dari hasil observasi yang dilihat pada saat pembelajaran. Observasi sikap demokratis peserta didik siklus I memperoleh rata-rata sebesar 57\% dengan kriteria cukup, meningkat pada siklus II menjadi $81 \%$ dengan kriteria sangat baik. Sedangkan angket sikap demokratis peserta didik pada siklus I memperoleh rata-rata sebesar 3,24 dengan kriteria baik, meningkat pada siklus II menjadi 3,42 dengan kriteria sangat baik.

Penerapan model pembelajaran Group Investigation (GI) pada tema 8 daerah tempat tinggalku juga dapat meningkatkan prestasi belajar peserta didik. Hal ini ditunjukkan adanya peningkatan ketuntasan belajar peserta didik pada siklus I ke siklus II. Siklus I dapat diperoleh nilai rata-rata 72,68 dengan ketuntasan belajar sebesar $66 \%$, 


\section{ELSE (Elementary School Education Journal) \\ Volume 3 Nomor 2 Agustus 2019 \\ P-ISSN: 2581-1800 E-ISSN: 2597-4122 \\ Email: else@um-surabaya.ac.id}

sedangkan pada siklus II diperoleh nilai rata-rata 79,69 dengan ketuntasan belajar sebesar $81 \%$ dengan kriteria sangat baik.

\section{Saran}

Berdasarkan kesimpulan dalam penelitian tindakan kelas (PTK) di atas, peneliti memberikan saran antara lain:

1. model pembelajaran Group Investigation (GI) merupakan model yang dapat diterapkan dalam pembelajaran tematik khusunya di Sekolah Dasar (SD), dan;

2. artikel ini dapat dijadikan sebagai bahan acuan untuk penelitian selanjutnya dengan berbagai pertimbangan dan perbaikan untuk lebih menyempurnakan hasil yang dicapai.

\section{DAFTAR PUSTAKA}

Ayun, A, F. 2016. Pendidikan Karakter Demokratis di Kelas IVA SD Negeri 1 Jampiroso Temanggung. Jurnal Pendidikan Guru Sekolah Dasar vol 5 No 25.2461-2469.

Arikunto, S ,dkk .2015. Penelitian Tindakan Kelas. Jakarta : Bumi Aksara.

Arsy, H. I., Prasetyo, A. P. B., \& Subali, B. (2019). Predict-Observe-Explain Strategy with Group Investigation Effect on Students' Critical Thinking Skills and Learning Achievement. Journal of Primary Education, 9 (1), 75-83.

Arifin, Z. 2013. Evaluasi Pembelajaran . Bandung : Remaja Rosdakarya.

Baki, A. etc.2010.The Application of Group Investigation Technique: The Views of the Teacher and Students. Turkish Journal of Computer and Mathematics Education Vol.1 No.2 166-186.

Kementrian Pendidikan Nasional .2010. Bahan Pelatihan Penguatan Metodologi Pembelajaran Berdasarkan Nilai-nilai Budaya untuk Membentuk Daya Saing dan Karakter Jakarta: Kemendiknas.

Mulyasa, E. 2013. Pengembangan dan Implementasi Kurikulum 2013. Bandung : Remaja Rosdakarya.

Mustari, M. 2014. Nilai Karakter : Refleksi untuk Pendidikan. Jakarta : Raja Grafindo Persada.

Pranata, E. 2016. Implementasi Model Pembelajaran Group Investigation (GI) Berbantuan Alat Peraga untuk Meningkatkan Kemampuan Pemahaman Konsep Matematika. Journal Pendidikan Matematika Indonesia, Vol 1 No 1. 34-38.

Slavin, R. E . 2008. Cooperative Learning . Bandung : Nusa Media. 